\title{
The Microphysiology of Peripheral Taste Organs
}

\author{
Stephen D. Roper \\ Department of Anatomy and Neurobiology, Colorado State University, Ft. Collins, Colorado 80523 and Rocky Mt. Taste \\ and Smell Center, University of Colorado Health Sciences Center, Denver, Colorado 80262
}

Vertebrate taste buds are tiny chemical sensors that ring the initial portion of the digestive tract, the oral cavity. ${ }^{1}$ These peripheral taste organs respond to a wide variety of chemical substances, from protons to proteins. Taste buds serve as a monitor of the chemical makeup of foodstufts before they are ingested, signaling via afferent nerves to the brain whether the food is poisonous or palatable. Each taste bud consists of 50-100 cells organized in a compact, ovoid structure within the oral epithelium. A tiny opening, or taste pore, connects the apical chemosensitive ends of the receptor cells to the external milieu (Fig. 1). Most, but not all, of the cells in the taste bud are chemosensory receptors, as will be discussed below. The number of taste buds is highly variable from individual to individual. In man, there can be from 2000 to 5000 taste buds distributed on the tongue, palate, and epiglottis. In extraordinary individuals, this number can range from as few as 500 to as many as 20,000 (I. Miller, personal communication).

\section{Chemosensory transduction mechanisms}

Taste receptor cells are particularly interesting to neurobiologists since taste cells generate an electrical signal in response to a diversity of chemical substances. Until recently, vertebrate taste organs have been difficult to study in detail because taste cells are not readily accessible to microelectrode impalements nor are they easy to preserve for electron microscopy (cf. Fig. 1). Nonetheless, due to new animal models and modern recording techniques, a great deal of information has been collected in the recent past concerning membrane events that take place during the activation of taste receptors. What is now known is that taste cells are electrically excitable and possess a spectrum of voltage-gated ion channels similar to those found on neurons (Roper, 1983, 1989a,b). The distribution of ion channels on the surface of taste receptor cells is especially revealing: a noninactivating, voltage-gated potassium conductance is concentrated on their apical, chemosensitive tips (Kinnamon and Roper, 1988;

\footnotetext{
I thank my colleagues Albertino Bigiani, Rona Delay, Doug Ewald, Tim Gilbertson, Sue Kinnamon, Ginger Sammonds, and Joan Welton for their helpful comments and technical assistance.

' In some animals, such as fish, taste buds are also situated outside the oral cavity in the epidermis on the head and body. For example, in channel catfish, taste buds are found over the entire body surface. Isolated taste cells can also be found in the epidermis in some species (Whitear, 1971).
}

Copyright (C) 1992 Society for Neuroscience 0270-6474/92/121127-08\$05.00/0
Kinnamon et al., 1988; Roper and McBride, 1989). ${ }^{2}$ The apical tip is the portion of the cell that is exposed to the external milieu. The apical, voltage-gated $\mathrm{K}^{+}$conductance of taste cells is partially active at rest, and this fact, combined with the focal distribution of $\mathrm{K}^{+}$channels on the exposed tips of taste receptor cells, makes these cells very sensitive to $\mathrm{K}^{+}$salts and to any chemical stimulus that modifies $\mathrm{K}^{+}$conductance. Indeed, acids (which taste sour) and many bitter-tasting compounds block the $\mathrm{K}^{+}$conductance in taste receptor cells (Kinnamon and Roper, 1988; Kinnamon et al., 1988; Cummings and Kinnamon, 1989; Spielman et al., 1989, 1991). This reduction in apical $\mathrm{K}^{+}$conductance may contribute to the early steps in sensory transduction for sour and bitter taste stimuli.

However, there is no one single mechanism underlying taste transduction. Instead, there is a constellation of membrane events occurring during sweet, sour, salty, and bitter taste stimulation, including direct ion permeation through open ion channels, activation of ligand-gated ion channels, ion channel modulation, G-protein activation, intracellular Ca release, and combinations of these and other events. For example, salt taste appears to be mediated by amiloride-sensitive $\mathrm{Na}^{+}$channels present in the apical membrane of receptor cells. Passive influx of $\mathrm{Na}^{+}$generates a depolarizing receptor current and triggers action potentials in taste receptor cells. Sugars bind to specific receptors; activate a G-protein; cause a rise in intracellular cAMP; and reduce basolateral $\mathrm{K}^{+}$conductance, thereby depolarizing the taste receptor cell. Certain bitter compounds, in addition to blocking apical $\mathrm{K}^{+}$conductance, stimulate the release of $\mathrm{Ca}^{2+}$ from intracellular stores via an inositol trisphosphate $\left(\mathrm{IP}_{3}\right)$ pathway. Sour stimuli (acids) in some species are transduced in part by proton permeation through amiloride-sensitive $\mathrm{Na}^{+}$channels (Fig. 2). Several excellent reviews summarize what is currently known about these mechanisms (Avenet and Lindemann, 1989; Teeter and Cagan, 1989; Kurihara, 1990; Avenet and Kinnamon, 1991; DeSimone, 1991; Simon, 1991).

Although it might seem reasonable that individual taste receptor cells possess a subset of the relevant membrane mechanisms for a particular taste stimulus, and consequently are

\footnotetext{
${ }^{2}$ Detailed studies on the distribution of $\mathrm{Na}^{+}, \mathrm{Ca}^{2+}$, and $\mathrm{K}^{+}$channels on the surface of taste cells have only been carried out to date on the large cells found in Necturus maculosus. The fact that mammals detect potassium salts as taste stimuli indicates that $\mathrm{K}^{+}$channels are also situated on the apical ends of mammalian taste cells. However, preliminary data suggest that the apical localization of $K^{\prime}$ conductance may not be as prominent or as ubiquitous in mammalian taste cells as in Necturus (T. Gilbertson, P. Avenet, S. Kinnamon, and S. Roper, unpublished observations).
} 

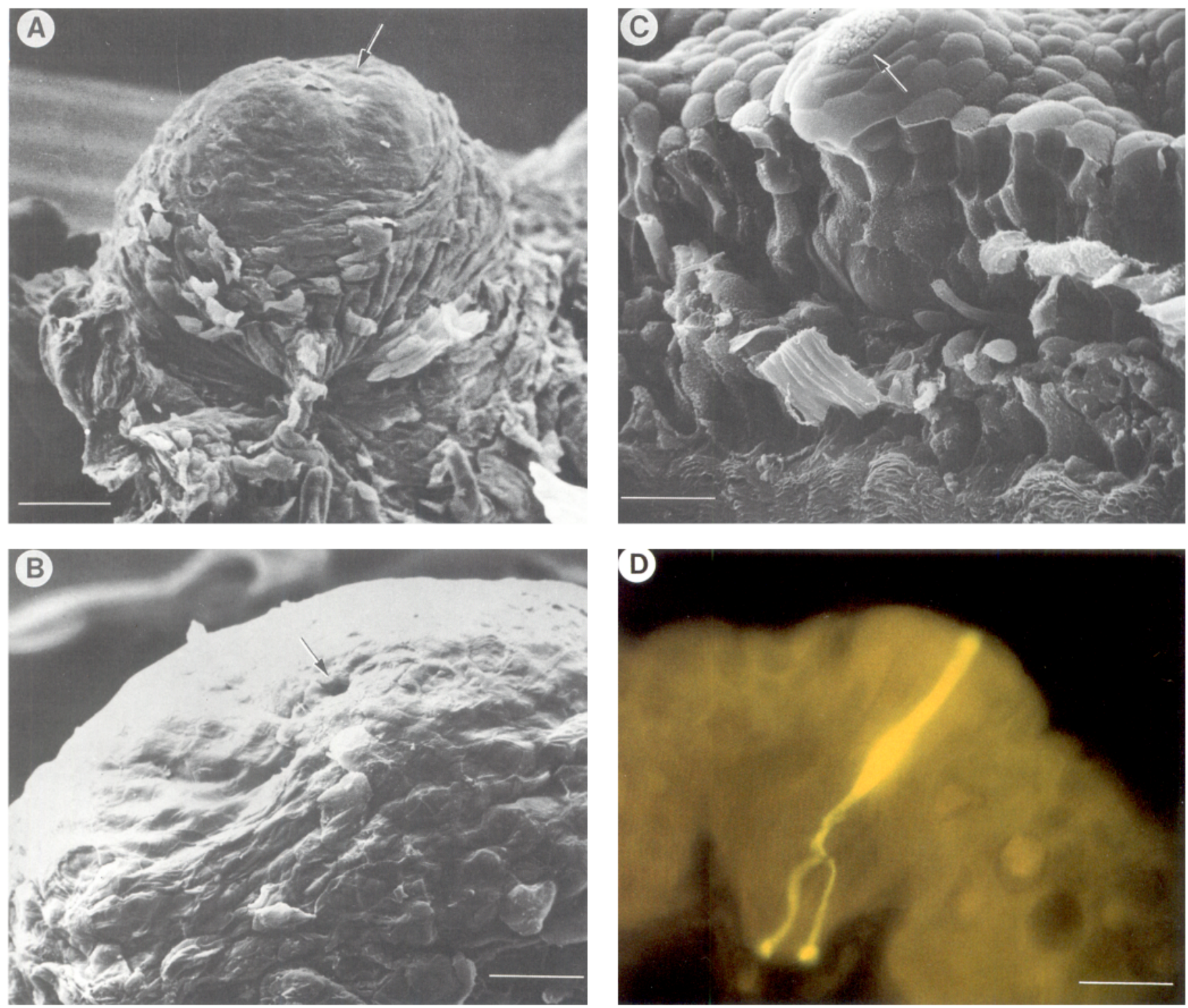

Figure 1. Taste buds from man and mudpuppy. A, Scanning electron micrograph (SEM) of fungiform papilla from author's tongue (note where forceps gripped the base of papilla during biopsy). At the apex is the narrow taste pore (arrow) through which taste stimuli gain access to the apical, chemosensitive tips of taste receptor cells. This micrograph illustrates the tough, keratinized tissue in which mammalian taste buds are embedded and which makes detailed microelectrode and electron microscopic studies difficult. $B$, Higher-magnification SEM of the taste pore (arrow), seen from a different angle. $C$, SEM of taste bud in Necturus maculosus, showing the large size of the epithelial cells and taste pore (arrow). The lingual epithelium was frozen and cracked apart to obtain this SEM. D. Necturus taste receptor cell filled with the fluorescent dye Lucifer yellow during a microelectrode impalement. $C$ and $D$ illustrate the large size of and ready access to taste cells in Necturus for detailed microphysiological studies. $A$ and $B$ courtesy of Rona Delay; $C$, courtesy of Tom Cummings and reprinted from Miller (1990); $D$, courtesy of Jian Yang and reprinted from Kinnamon (1988). Scale bars: $A, 200 \mu \mathrm{m} ; B, 80 \mu \mathrm{m} ; C$ and $D, 20 \mu \mathrm{m}$.

"tuned" to only one of the basic taste qualities, for example, sweet-sensitive or bitter-receptive taste cells, the data are equivocal. Intracellular microelectrode recordings suggest that individual taste cells respond to more than a single taste quality (Sato, 1986). However, it is likely that early studies using intracellular impalements to record receptor potentials in taste cells were complicated by cell injury and by artifactual junction potentials generated when chemical stimuli were applied to the lingual surface. Modern recording techniques, employing patch electrodes and $\mathrm{Ca}^{2+}$ - and voltage-sensitive dyes, may yet reveal that individual taste cells exhibit more selectivity in their chemosensitivity. This remains to be tested.

\section{Synaptic processing in the taste bud}

An important topic concerning peripheral taste reception that has recently resurfaced is the question of synaptic transmission in taste buds. No neurotransmitters in taste buds have been identified unambiguously to date, yet it is clear that chemical and electrical synaptic transmission occurs in taste organs. The obvious location for synapses is between receptor cells and sensory afferent axons, and early attempts to identify the neurotransmitters in taste buds focused on this site. However, recent studies indicate that synapses, both chemical and electrical, occur between cells within the taste bud (Fig. 3). In particular, 


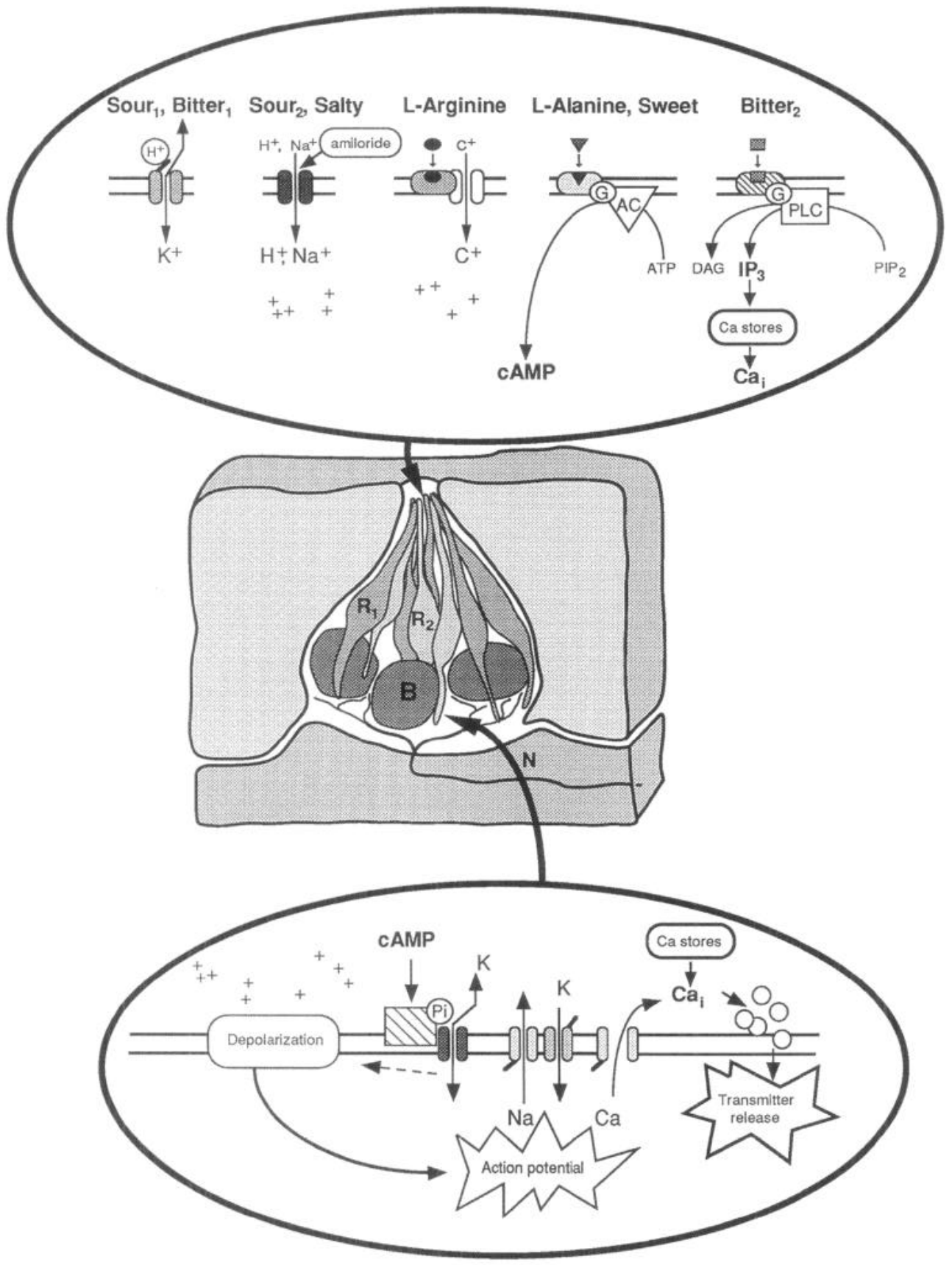

Figure 2. Summary of chemosensory transduction mechanisms occurring in taste buds. Events illustrated at the apical membrane of taste receptor cells include protons (sour) and bitter compounds blocking $\mathrm{K}$ channels; protons and $\mathrm{Na}^{+}$passing through apical, amiloride-sensitive sodium channels; L-arginine binding to a ligand-gated, nonselective cation channel; L-alanine and sweet compounds activating a G-protein by binding to appropriate membrane receptors and stimulating adenylate cyclase $(A C) ;$ and bitter compounds activating a G-protein that is coupled to phospholipase C (PLC) and resulting in an increase in $\mathrm{IP}_{3}$. Events illustrated on the basolateral membranes of taste receptor cells include depolarization of the membrane consequent to an influx of cations at the apical membrane; reduction of potassium conductance due to cAMP buildup, which also depolarizes the membrane; generation of an action potential when the depolarization reaches threshold; influx of $\mathrm{Ca}^{2+}$ ions; and release of neurotransmitter stores consequent to increased $\left[\mathrm{Ca}^{2+}\right]_{i} . \mathrm{C}^{+}$, cations; $G$, G-protein; $A C$, adenylate cyclase; $P L C$, phospholipase C; $D A G$, diacyl glycerol; $I P_{3}$, inositol 1,4,5-trisphosphate; $P I P_{2}$, inositol 4,5-bisphosphate; $R$, taste receptor cell; $B$, basal taste cell; $N$, nerve bundle. Modified from Avenet and Kinnamon (1991) and Ewald and Roper (in press). electron microscopic analyses of amphibian taste buds indicate that one type of cell in taste buds, the Merkel-like basal taste cell, often forms synapses with adjacent receptor cells as well as with sensory axons (e.g., Reutter, 1978; Delay and Roper, 1988). Thus, it appears as if some basal cells are interneurons and others are stem cells. Intracellular impalements from basal cells that are presumed to be interneurons have revealed postsynaptic potentials elicited by chemosensory stimulation (Ewald and Roper, in press). Furthermore, intracellular dye injections have revealed that receptor cells are dye coupled (West and Bernard, 1978; Teeter, 1985; Yang and Roper, 1987; Sata and Sato, 1989), presumably through gap junctions (Akisaka and Oda, 1978). A study by West and Bernard (1978) suggested that current injected into one taste cell was transmitted to adjacent cells via electrical junctions, and this is actively being investi- gated with more modern recording techniques (Bigiani and Roper, 1991).

Taken together, the morphological and functional studies suggest that "cross talk" via lateral synaptic interactions occurs in peripheral taste organs (Roper, 1989a). Lateral synaptic interactions could serve to process the initial signals and to modulate the output of the taste bud, but how and to what extent this actually occurs are unanswered questions.

One way to answer these questions would be to determine the identity of the neurotransmitters in taste buds and study how appropriate agonists and antagonists modify the function of the peripheral taste organs. Progress on identifying neurotransmitters in peripheral taste organs has been slow. The following paragraphs summarize the current status of the search for these transmitters. 


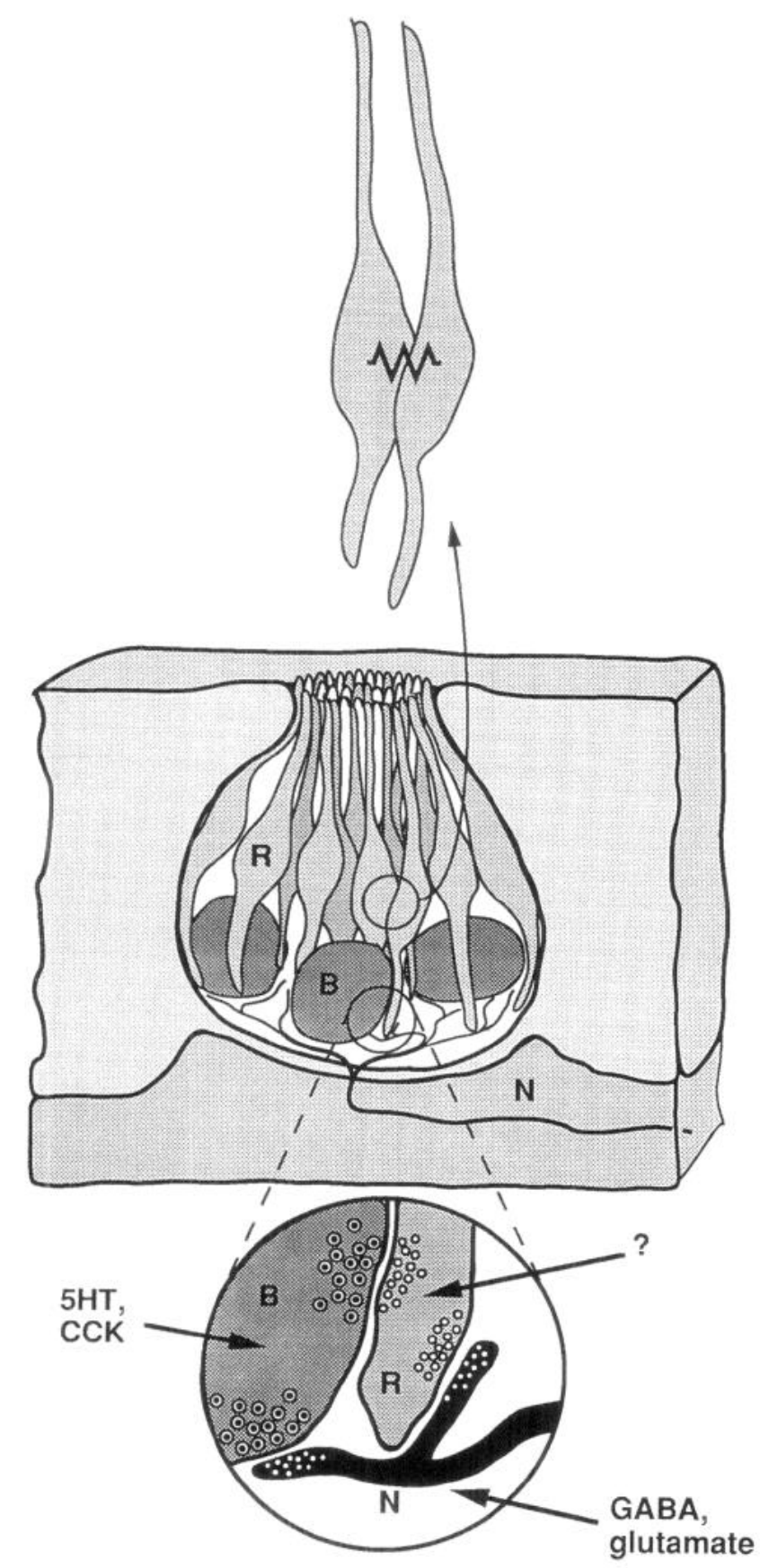

Figure 3. Schematic drawing of a taste bud from Necturus, illustrating synaptic contacts and putative neurotransmitters. Top, Electrical connections join adjacent taste receptor cells. Bottom, Synaptic contacts at the basolateral region include synapses between taste receptor cells and sensory nerve terminals, between taste receptor cells and basal taste cells, and between basal taste cells and sensory nerve terminals. $R$, taste receptor cell; $B$, basal taste cell; $N$, nerve fibers; $5 H T$, serotonin; $C C K$, cholecystokinin; $G A B A, \gamma$-amino butyric acid. Modified from Ewald and Roper (in press).

Acetylcholine. Early investigators were influenced by histochemical studies indicating that acetylcholinesterase (AChE) was present at the base of taste buds where the nerve supply entered. Relatively high concentrations of cholinergic agonists and antagonists were applied topically onto the tongue or perfused through the lingual artery in an attempt to reach synaptic sites buried within taste buds (Landgren et al., 1954; Tateda and Beidler, 1964; Rapuzzi et al., 1969). Although alterations in taste reception were indeed observed, later investigators ascribed the findings to pharmacological actions unrelated to cholinergic neurotransmission (Duncan, 1964; cf. Morimoto and Sato, 1982). Furthermore, a critical enzyme in the biosynthetic pathway for ACh, choline acetyltransferase (ChAT), has not been observed in vertebrate taste buds. In fact, where attempts have been made to localize ChAT in taste tissues, the results have been negative (J. Welton, R. Taylor, A. J. Porter, and S. D. Roper, unpublished observations). The bulk of what little evidence there is points against cholinergic transmission in taste buds.

Amino acids. Many amino acids are taste stimuli when they act on the chemosensitive apical ends of taste receptor cells. For example, glycine tastes sweet to humans and glutamate elicits a unique taste sensation termed "umami" (translate "deliciousness") by the Japanese (Schiffman et al., 1981; Kawamura and Kare, 1987), yet these same substances are powerful neurotransmitters in the CNS. It is conceivable that amino acids may serve a dual function in taste buds-as taste stimuli and as neurotransmitters. Indeed, Jain and Roper (1991) identified GABAand glutamate-containing axons in the taste bud (Fig. 4). Lu and Roper (in press) extended these observations to the electron microscopic level and identified glutamate-immunoreactive fibers innervating taste cells. An older report in the literature mentions that GABA, when applied topically to the tongue, seemed to have an inhibitory influence on the output of taste buds in the rat (Tateda and Beidler, 1964), but there have been no systematic studies on whether or how amino acids act at synaptic sites in taste buds.

Neuropeptides. With the advent of modern immunocytochemical technology, researchers have been busy cataloging peptides in the vertebrate taste bud. A variety of neuropeptides, including bombesin, cholecystokinin, calcitonin gene-related peptide (CGRP), galanin, gastrin-releasing peptide, peptide $\mathrm{HI}$, substance $\mathrm{P}$, and vasoactive intestinal peptide have been localized to taste cells and their nerve supply (see Welton et al., unpublished observations, for review).

Much of the attention has focused on the localization and actions of substance P. Substance P is present in a subset of nerve fibers that penetrate the taste buds and pass near, but do not directly innervate, taste cells (Yamasaki et al., 1984). Researchers have speculated that afferent taste fibers containing substance $\mathrm{P}$ mediate nociception or sensations elicited by capsaicin (an active ingredient of chili peppers), but the absence of direct synaptic contacts between substance $\mathrm{P}$-containing fibers and taste receptor cells seems to repudiate this. Esakov and his colleagues found that substance $\mathrm{P}$, injected intraperitoneally or directly into the tongue, regulates the 5-HT content of basal taste cells (Solov'eva and Esakov, 1984) and increases sensory afferent nerve responses to salt and acid stimuli (Esakov and Serova, 1988). Thus, either by its direct action on taste cells or indirectly via serotonergic mechanisms, substance P may modulate the sensitivity of peripheral taste organs. Alternatively, the earliest descriptions of the actions of substance $\mathrm{P}$ included that it stimulated salivary secretion (Leeman and Hammerschlag, 1967). Since taste buds are believed to secrete mucus into their taste pore (cf. Cummings et al., 1987), it is conceivable that one function of the peptide is to stimulate taste cells to release apical secretions. Lastly, some authors have speculated that substance $\mathrm{P}$ plays a trophic role in the maintenance and regeneration of 

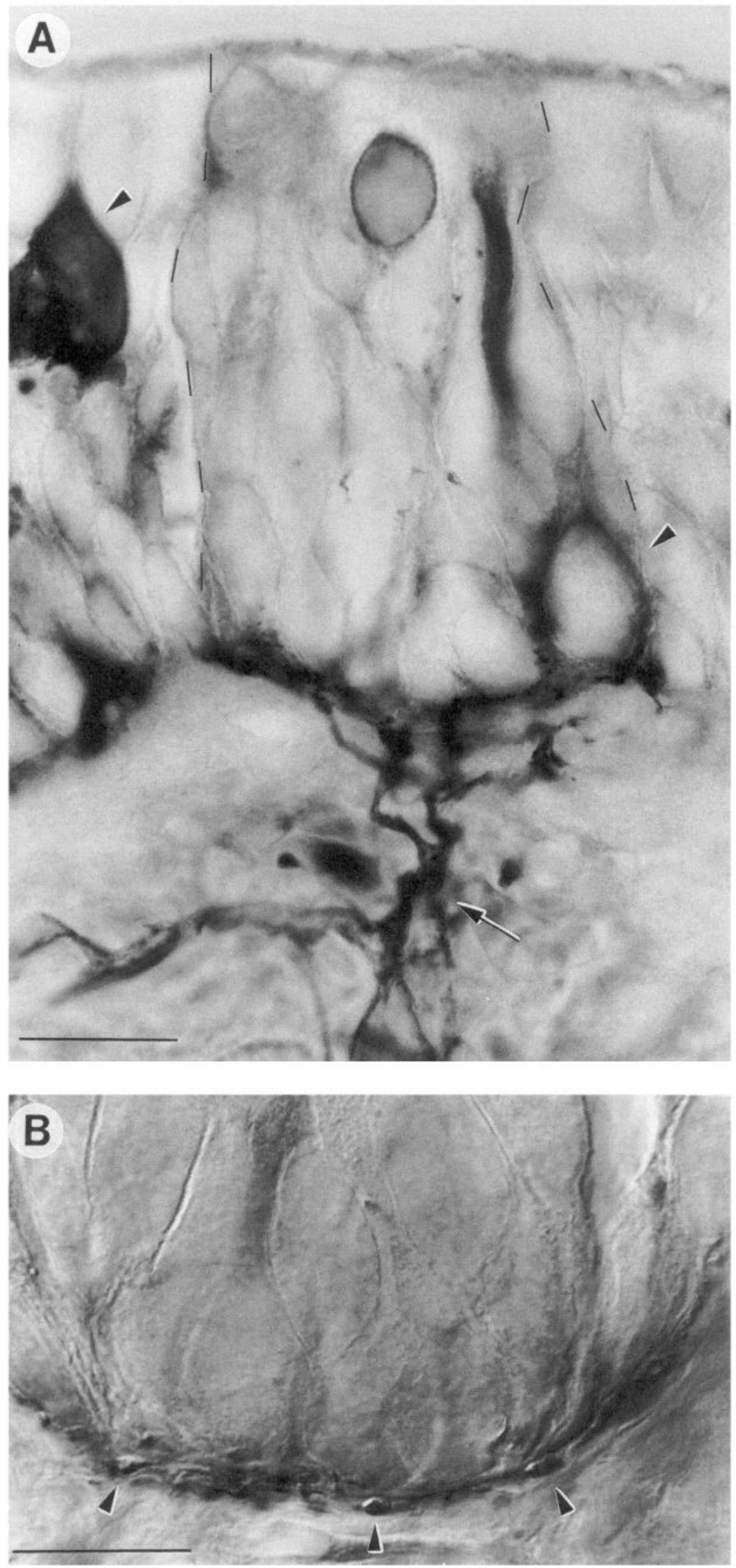

Figure 4. Immunocytochemical demonstration of glutamate in the Necturus taste bud. $A$, Bright-field micrograph of a 20- $\mu \mathrm{m}$-thick section of Necturus lingual epithelium, illustrating dense reaction product in nerve fibers (arrow) that innervate the taste bud and in some cells in the taste bud and surrounding epithelium (arrowheads). No counterstain was used in this section, and hence the outline of the taste bud is difficult to see in this micrograph. Broken lines show the approximate boundary of the taste bud. Immunostaining in cells was shown not to be selective for glutamate, unlike the specific anti-glutamate immunostaining in the nerve fibers. $B$, Differential contrast optics micrograph illustrating immunopositive nerve terminals at the base of another Necturus taste bud stained with Glu-2 antibody. Varicosities (arrowheads) can be seen in close apposition to cells in the base of the taste bud. From Jain and Roper (1991). Scale bars: $A, 30 \mu \mathrm{m} ; B$, $20 \mu \mathrm{m}$. 
Figure 5. Immunocytochemical demonstration of 5-HT in the frog taste organ. Differential interference contrast micrograph of a $20-\mu \mathrm{m}$ thick section of lingual epithelium in the frog, showing a taste disk. No counterstain was used in this tissue, making it difficult to discern individual receptor cells and other cells of the large, round taste organ. The arrows point to a horizontally disposed layer of immunopositive (serotonergic) cells near the base of the taste bud. Modified from Jain and Roper (1991). Scale bar, $40 \mu \mathrm{m}$.

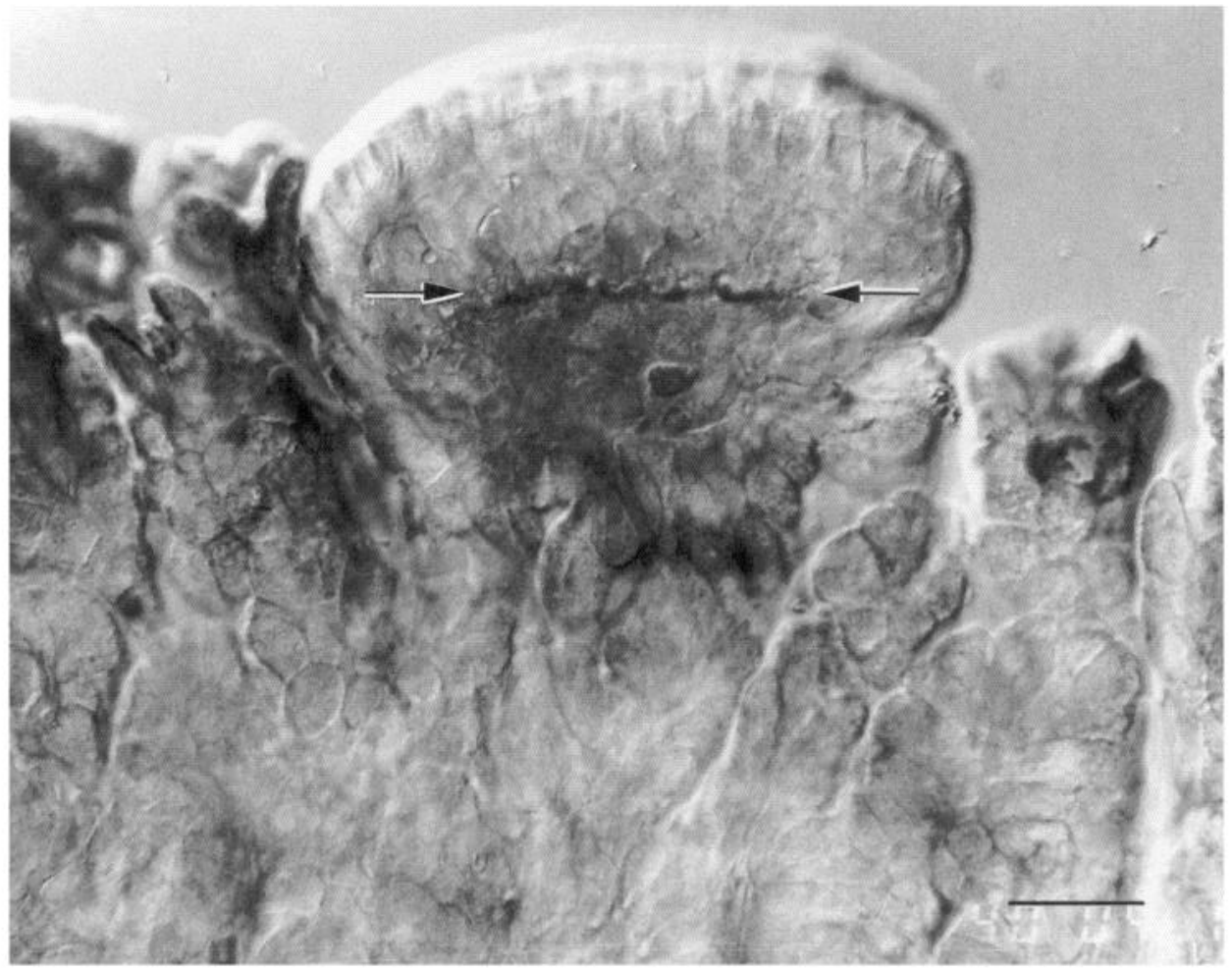

taste cells (e.g., Yamasaki et al., 1984, 1985; Kinnman and Aldskogius, 1991). The experimental evidence for any of the above functions is not compelling. Furthermore, when substance $\mathrm{P}$-containing fibers in the tongue were experimentally eliminated in rats, there were no clear-cut effects on taste (Silver et al., 1985).

The functions of the remaining peptides found in taste organs have not been explored. Some authors have speculated that CGRP (like substance P) exerts a trophic influence on taste buds (Kinnman and Aldskogius, 1991; Montavon et al., 1991).

Amines. There are ample data showing the presence of biogenic amines, specifically noradrenalin and 5-HT, in vertebrate taste buds. DeHan and Graziadei (1973) were among the first to apply Falk-Hillarp histofluorescent techniques to lingual tissue. They concluded that catecholamine was present in taste cells. These observations have been repeated and extended by numerous investigators in a variety of species. However, closer analysis of the histofluorescence emission spectrum led Nada and Hirata (1975) to conclude that the monoamine serotonin, rather than a catecholamine, was present in taste cells. Immunocytochemical and electron microscopic studies have vindicated this latter report (Takeda and Kitao, 1980; Welton et al., unpublished observations; see Roper, 1992, for other references) (Fig. 5). Consensus now is that 5-HT is present in one category of small round cells (Merkel-like basal cells) at the base of taste buds of lower vertebrates, and in elongate receptor cells (type III cells) in mammalian taste buds. Serotonergic basal cells of lower vertebrates closely resemble cutaneous Merkel cells, as has been pointed out by a number of investigators. The significance of this similarity between Merkel cells and serotonergic basal taste cells, and the physiological role of these cells in taste organs are unknown. Furthermore, it is unclear what the relationship, if any, is between Merkel-like basal cells in lower ver- tebrates and serotonergic, type III receptor cells in mammalian taste buds.

Biogenic amines have a profound influence on taste. Serotonergic mechanisms are known to be involved in controlling feeding, specifically in reducing food intake. Although 5-HT is believed to be acting in the CNS and perhaps in the gut to produce this anoretic effect (Hoebel, 1977; Fletcher and Burton, 1984), it is also possible that 5-HT may be acting directly on peripheral taste receptors. For example, 5-HT enhances peripheral sensory sensitivity in a variety of tissues (cf. Birrell et al., 1990), and given its localization to specific cells in taste buds, it is reasonable to hypothesize that this monoamine is a potential neurotransmitter or neuromodulator in peripheral taste organs. Similarly, the effects of adrenalin and noradrenalin on sensory organs, including taste buds, have long been known. For example, Chernetski (1964) stimulated the sympathetic supply to the frog tongue and showed that this enhanced the responsiveness of taste organs. The evidence, however, only hints at the possibility that biogenic amines are somehow involved in peripheral taste bud function.

More direct attempts have made to test whether adrenalin, 5-HT, and related compounds influence peripheral taste mechanisms, especially synaptic transmission in taste buds. Investigators have perfused agents through the lingual artery or injected them subepithelially into the tongue and tested gustatory nerve responses to common taste stimuli. The results have been rather contradictory and confusing. Kurihara, Sato, and their colleagues have concluded that noradrenalin is the transmitter between taste cells and sensory afferent fibers (Morimoto and Sato, 1975, 1977, 1982; Nagahama and Kurihara, 1985). In contrast, Esakov et al. (1983) found 5-HT the more likely neurotransmitter candidate. However, it is difficult with confidence to pinpoint taste cell synapses as the specific targets for these 
pharmacological manipulations. It is impossible to rulc out indirect actions of catecholamines and monoamines when they are injected via arterial perfusion or injected subepithelially. Moreover, the absence of catecholamines in taste organs ( $\mathrm{Nada}$ and Hirata, 1975) and the inability to detect tyrosine hydroxylase, the biosynthetic enzyme for dopamine, adrenalin, and noradrenalin, in taste buds (Kuramoto, 1988; Wclton et al., unpublished observations) are findings that are inconsistent with adrenergic synaptic mechanisms.

The role of biogenic amines in peripheral taste processing thus remains clouded. Which amine, if any, is culpable? Does an amine act at synaptic sites in taste buds? Or, do amines directly modulate the apical chemosensitivity of taste receptor cells? Alternatively, do biogenic amines act only secondarily on taste buds by influencing vasculature or other surrounding tissues? Our current understanding of the microphysiology of taste organs does not include answers to these questions.

\section{Summary}

Recent studies on how peripheral taste organs function have revealed a number of intriguing membrane mechanisms underlying taste transduction. The story is still evolving, but certain generalities can now be stated confidently. For example, there is no one single chemosensory membrane transduction event. Instead, the different taste qualitics-sweet, sour, salty, bitter-are subserved by different mechanisms.

Furthermore, chemical and electrical synaptic processing in the taste bud is likely to modulate the output of the taste organs and may contribute to how different taste qualities are discriminated. Synapses occur between adjacent cells in the taste organ as well as between receptor cclls and sensory fibers. The preponderance of data indicates that biogenic amines are present in taste buds and exert some form of neuromodulatory control, if not frank neurotransmission, in peripheral taste organs.

Current research in the microphysiology of taste buds includes cxtending and refining our understanding of how the apical, chemosensitive regions of receptor cells respond to taste stimuli, identify...ig what synaptic transmitters exist in taste organs, and exploring synaptic mechanisms in taste buds.

\section{References}

Akisaka T, Oda M (1978) Taste buds in the vallate papillae of the rat studied with freeze-fracture preparation. Arch Histol Jpn 41:87-98.

Avenet P, Kinnamon SC (1991) Cellular basis of taste reception. Curr Opin Neurobiol 1:198-203.

Avenet P, Lindemann B (1989) Perspectives of tastc reception. J Membr Biol 112:1-8.

Bigiani A, Roper SD (1991) Membrane capacitance measures electrical coupling between taste cells. Soc Neurosci Abstr 17:1216.

Birrell GJ, McQueen DS, Iggo A, Grubb BD (1990) The effects of 5-HT on articular sensory receptors in normal and arthritic rats. $\mathrm{Br}$ J Pharmacol 101:715-721.

Chernetski KE (1964) Sympathetic enhancement of peripheral sensory input in the frog. $\mathbf{J}$ Neurophysiol 27:493-515.

Cummings T, Kinnamon S (1989) Single-channel properties of the apical K conductance in Necturus taste cells: modulation by ATP, Ca and taste stimuli. In: ISOT X: proceedings of the 10th international symposium on olfaction and taste (Doving KB, ed), p 280. Oslo: GSC Press.

Cummings TA, Delay RJ, Roper SD (1987) Ultrastructure of apical specializations of taste cells in the mudpuppy, Necturus maculosus. J Comp Neurol 261:604-615.

DeHan RS. Graziadei PPC (1973) The innervation of frog's taste organ. Life Sci 13:1435-1449.

Delay RJ, Roper SD (1988) Ultrastructure of taste cells and synapscs in the mudpuppy Necturus maculosus. J Comp Neurol 277:268-280.
DeSimone JA (1991) Transduction in taste receptors. Nutrition 7 $146-149$.

Duncan CJ (1964) Synaptic transmission at taste buds. Nature 203: 875-876.

Esakov AI, Serova ON (1988) Influence of substandce $P$ on taste receptor organ and salt solution intake in rats. Neurosciences 14: 321-327.

Esakov AI, Golubtsov KV, Solov'eva NA (1983) The role of serotonin in taste reception in the frog Rana temporaria. J Evol Biochem Physiol 19:56-61.

Ewald D, Roper S (in press) Intercellular signalling in Necturus taste buds: chemical excitation of receptor cells clicits responses in basal cells. J Neurophysiol, in press.

Fletcher PJ, Burton MJ (1984) Effects of manipulations of peripheral serotonin on feeding and drinking in the rat. Pharmacol Biochem Behav 20:835-840.

Hocbel BG (1977) Pharmacological control of feeding. Annu Rev Pharmacol Toxicol 17:605-621.

Jain S, Roper SD (1991) Immunocytochemistry of gamma-aminobutyric acid, glutamate, serotonin and histamine in Necturus taste buds. J Comp Neurol 307:675-682.

Kawamura Y, Kare MR (1987) Umami: a basic taste. New York: Dekker.

Kinnamon S (1988) Taste transduction: a diversity of mechanisms. Trends Neurosci 11:491-496.

Kinnamon SC, Roper SD (1988) Evidence for a role of voltage-sensitive apical $\mathrm{K} \cdot$ channels in sour and salt taste transduction. Chem Senses 13:115-121.

Kinnamon SC, Dionne VE. Beam KG (1988) Apical localization of $\mathrm{K}^{+}$channels in taste cells provides the basis for sour taste transduction. Proc Natl Acad Sci USA 85:7023-7027.

Kinnman E. Aldskogius H (1991) The role of substance $P$ and calcitonin gene-related peptide containing nerve fibers in maintaining fungiform taste buds in the rat after a chronic chorda tympani nerve injury. Exp Neurol 113:85-91.

Kuramoto $\mathrm{H}$ (1988) An immunohistochemical study of cellular and nervous elements in the taste organ of the bullfrog. Rana catesbeiana. Arch Ifistol Cytol 51:205-221.

Kurihara K (1990) Molecular mechanisms of reception and transduction in olfaction and taste. Jpn J Physiol 40:305-324.

Landgren S, Liljestrand G, Zotterman Y (1954) Chemical transmission in taste fiber endings. Acta Physiol Scand 30:105-114.

Leeman SE, Hammerschlag R (1967) Stimulation of salivary secretion by a factor extracted from hypothalamic tissue. Endocrinology 81 : 803-810.

Lu K-S, Roper SD (in press) Electron microscopic immunocytochemistry of glutamate-containing nerve fibers in the taste bud of the mudpuppy (Necturus maculosus). J Electron Microsc Tech, in press.

Miller JA (1990) A matter of taste. Bioscience 40:78-82.

Montavon P, Lindstrand K, Luts A, Sundler F (1991) Peptide-containing nerve fibers in the fungiform papillae of pigs and rats. Reg Peptides 32:141-150.

Morimoto K, Sato M (1975) Noradrenaline as a chemical transmitter from taste cells to sensory nerve terminals in frog. Proc Ipn Acad Sci $51: 347-352$.

Morimoto K, Sato M (1977) Is serotonin a chemical transmitter in the frog taste organ? Life Sci 21:1685-1696.

Morimoto K, Sato M (1982) Role of monoamines in afferent synaptic transmission in frog taste organ. Jpn J Physiol 32:855-871.

Nada O, Hirata K (1975) The occurrence of the cell type containing a specific monoamine in the taste bud of the rabbit's foliate papilla. Histochemistry 43:237-240.

Nagahama S, Kurihara K (1985) Norepinephrinc as a possible transmitter involved in synaptic transmission in frog taste organs and $\mathrm{Ca}$ dependence of its release. J Gen Physiol 85:431-442.

Rapuzzi G, Violante A. Casella C (1969) Relation between ATP and chemical transmitters in the frog's receptors. In: Olfaction and taste III (Pfaffman C, ed), pp 392-396. New York: Rockefeller UP.

Reutter K (1978) Taste organ in the bullhead (Teleostei). Adv Anat Embryol Cell Biol 55:1-98.

Roper S (1992) Synpatic transmission and neuromodulation in peripheral taste organs. In: The science of food regulation (Bray $G$, Ryan A, eds), pp 436-560. Baton Rouge: LSU Press.

Roper SD (1983) Regenerative impulses in taste cells. Science 220: $1311-1312$. 
Roper SD (1989a) The cell biology of vertebrate taste receptors. Annu Rev Neurosci 12:329-353.

Roper SD (1989b) Ion channels and taste transduction. In: Chemical senses (Brand JG, Teeter JH, Cagan RH, Kare MR, eds), pp 137149. New York: Dekker.

Roper.SD, McBride DWJ (1989) Distribution of ion channels on taste cells and its relationship to chemosensory transduction. J Membr Biol 109:29-39.

Sata O, Sato T (1989) Dye-coupling among cells in taste disk in frog. Chem Senses 14:316.

Sato T (1986) Receptor potential in rat taste cells. Prog Sensory Physiol $6: 1-37$.

Schiffman SS, Sennewald K, Gagnon J (1981) Comparison of taste qualities and thresholds of $\mathbf{D}$ - and $\mathbf{L}$-amino acids. Physiol Behav 27: $51-59$.

Silver WL, Mason R, Marshall DA, Maruniak JE (1985) Rat trigeminal, olfactory and taste responses after capsaicin desensitization. Brain Res 333:45-54.

Simon S (1991) Mechanisms of sweet taste transduction. In: Sweeteners: discovery, molecular design, and chemoreception (Walters DE, Orthoefer FT, Dubois GE, eds), pp 237-250. Washington, DC: American Chemical Society.

Solov'eva NA, Esakov AI (1984) Effect of substance P on the monoamine-containing cells of the taste buds. Biull Eksp Biol Mcd 98:389390.

Spielman AI, Mody I, Brand JG, Whitney G, MacDonald JF, Salter MW (1989) A method for isolating and patch-clamping single mammalian taste receptor cells. Brain Res 503:326-329.
Spielman AI, Huque T, Brand JG, Whitney G (1991) The mechanism of sucrose octaacetate (bitter taste) signal transduction. Chem Senses 16:585.

Takeda M, Kitao K (1980) Effect of monoamines on the taste buds in the mouse. Cell Tissue Res 210:71-78.

Tateda H, Beidler LM (1964) The receptor potential of the taste cell of the rat. J Gen Physiol 47:479-486.

Teeter JH (1985) Dye-coupling in catfish taste buds. In: Proceedings of the 19th Japanese symposium on taste and smell (Kimura S, Miyoshi A, Shimida I, eds), pp 29-33. I Iozumi-cho, Gifu, Japan: Asahi University.

Teeter JH, Cagan RH (1989) Mechanisms of taste transduction. In: Neural mechanisms in taste (Cagan RH, ed), pp 1-20. Boca Raton, FL: CRC.

West CHK, Bernard RA (1978) Intracellular characteristics and responses of taste bud and lingual cells of the mudpuppy. J Gen Physiol 72:305-326.

Whitear M (1971) Cell specialization and sensory function in fish epidermis. J Zool (Lond) 163:237-264.

Yamasaki H, Kubota Y, Takagi H, Tohyama M (1984) Immunoelectron-microscopic study on the fine structure of substance-P-containing fibers in the taste buds of the rat. J Comp Neurol 227:380-392.

Yamasaki H, Kubota Y, Tohyama M (1985) Ontogeny of substance $P$-containing fibers in the taste buds and the surrounding epithelium. I. Light microscopic analysis. Dev Brain Res 18:301-305.

Yang J, Roper SD (1987) Dye-coupling in taste buds in the mudpuppy, Necturus maculosus. J Neurosci 7:3561-3565. 